\title{
Mediated Digital Activism: A Critical Assessment of Opportunities, Promises and Problems of Social Media Uses in Contemporary Grassroots Movements
}

\author{
Baruck Opiyo, Eastern Mediterranean University, North Cyprus \\ Ülfet Kutoğlu Kuruç, Eastern Mediterranean University, North Cyprus
}

\begin{abstract}
The rapid development and widespread and increasing use of Social Networking sites is arguably one the most significant developments in contemporary human communication over the past two decades. Indeed, perhaps comparable only to development of mobile communication technologies, social networking may well be one of the most important and visible forms of human interaction since the invention of the Internet. In this paper, we examine and highlight the enormous potential of these fairly recent technological developments and highlight opportunities they present to humankind as platforms for democratic and participatory communication and governance - especially in grassroots social movements activism. While doing so, we use cases to show the important potential and actual contributions that social media hold out and represent for democratic communication. The paper also casts a critical look at the potential risks and examines proven and theoretical shortcomings and challenges that these new advances in human communication may pose or represent for society, and identify cybercrime, cyber bullying, their effects on human physical and emotional health, their impact on productivity and other workplace complications, and potential societal disorder and dysfunction of certain social norms among the list of concerns that we suggest require further reflection and redress. The paper concludes by depicting social media as a potentially useful tool from which much social and societal capital can be derived; but also draws attention to their many problematic aspects that make them seem like doubleedged sword - with enormous opportunities and benefits on the one hand, and risks and threats, on the other, depending primarily on the uses to which they are put. Global, regional and national initiatives should be taken to maximize the benefits of social media while minimizing, or at least containing the threats through incorporation of independent but limited guidelines and regulations that would safeguard people's freedoms and rights while protecting users from abuses and adverse effects often inherent in new developments.
\end{abstract}


Keywords: social media, cyber-democracy, cybercrime, social media activism, conflict, participatory democracy, conflict sensitive journalism, social media literacy.

\section{Introduction}

The U.S. Republican party presumptive nominees in the 2016 presidential race has stirred a fair amount of controversy both inside the country and internationally. In response to one of the many controversial comments by Donald Trump - calling for Muslims to be temporarily banned from entering the United States, five mosques in Scotland teamed up in a campaign to send special invitation to the Republican party's imminent presidential flag bearer to visit the mosques and "educate himself" about Islam and Muslims during a visit to Scotland in the third week of June 2016 during a trip to re-launch his newly renovated Turnberry golf course and hotel there. Campaigners said that if Trump declined or did not respond to their invitation to visit the mosques they would hire a plane to "fly a banner over Trump's head" as he reopens his new expensive facility "to make sure he gets the invite," reported The (Glasgow, Scotland) Herald newspaper (quoted in USA TODAY: http://www.usatoday.com/story/news/world/2016/06/10/donald-trump-scotlandcoward/85684514/). Efforts by the five mosques to invite the US Republican presidential candidate for a firsthand, face-to-face, dialogic and democratic encounter with Muslims and Islam, came amid outrage that some of his remarks had stirred in local and international political circles. Both British Prime Minister, David Cameron and newly-elected mayor of London Sadiq Khan called him "ignorant," and Scottish Liberal Democrat leader Willie Rennie said Trump "may have closed his mind to other cultures but it seems Edinburgh's Muslim community are ready to open their doors to The Donald and teach him about Islam." (ibid).

At the same time, a U.K.-based Social movement activist group called "38 Degrees" quickly joined the initiative by the five mosques by launching its own Online campaign by using their social media web page to collect signatures of tens of thousands to pressure Trump to acknowledge and accept the invitation by the mosques. 38 Degrees was founded in May 2009, and says of its mission that, "38 Degrees brings over two million of us together to take action on the issues that matter and bring about real change. 38 Degrees makes it easy and quick for hundreds of thousands of us to come together to take action on the issues we care about. From tackling poverty to safeguarding our schools and hospitals, protecting our 
environment to holding our MPs to account, 38 Degrees brings people together to make a difference." To highlight one more example of what Online communities are increasingly becoming able to achieve through social media-based activism, 38 degrees collected 70,000 signatures in 2015 to lobby Robert Gordon University in Aberdeen, Scotland, to revoke an honorary doctor of Business Administration which it had awarded Donald Trump in 2010, arguing at the time that, "his views did not match the values of Robert Gordon University" (any more). The honorary degree was revoked in December 2015 mostly following Trump's call for all Muslims to be banned from entering the United States. Invitation for first-hand encounter and dialogue with imams of the five mosques therefore comes as a second phase of the controversy. As it turned out neither 38 Degrees nor the five mosques carried out their threat to fly a plane with a message of the New York billionaire turned presidential candidate's head; but the furor was adequate to have Trump change his position on the matter, saying he would be just fine with "Muslims from Scotland visiting the United States" as reported by the New York Daily News of June 25, 2016 (http://www.nydailynews.com/news/politics/donald-trump-scottish-muslims-coming-u-sarticle-1.2688094).

Although actions and activities of 38 Degrees may seen isolated or rare, it's undeniably evident that Online-based activism is on the rise and social media such as Facebook and Twitter are impacting and influencing the ways in which a variety of communicators engage and influence their publics; many of whom are no longer hostage to the limitations and shortcomings of the gatekeeping activities of editors of traditional media. Rather, through social media, they are able to send, share or broadcast their messages to anyone who cares to hear, view or read them (Ross and Burger, 2014). On the public's side, it's now possible to follow politicians and other people of interest on Twitter or have a Facebook fan page comment on their tweets and posts, and even send them messages directly and engage them or seek their support for a cause just as 38 Degrees appears to have successfully done and continues to do with regard to Donald Trump. Following the historic decision and vote in a referendum by U.K. voters to quit the EU, a citizen activists launched an online signature campaign to try to compel Britain's political leaders to consider a rerun of the vote. After just three days, the campaign had collected more than 3 million signatures on UK Parliament website 
(http://www.telegraph.co.uk/news/2016/06/25/more-than-half-a-million-sign-petitiondemanding-referendum-reru/ ). Quite democratic and participatory these social media - with the attending new technologies for speedy communication - are, one can say. At least in so far as the potential for democratic and participatory communication go. In their ground breaking theoretical analogy of models of public relations practice, while analyzing communication models in the field of public relations, Grunig and Hunt (1984) outlined four models that they argued sum up contemporary public relations practices; a) one-way models which incorporate "Press agent/publicity" model, and "public information" model on the one hand, and b) two-way models that incorporate "two-way asymmetrical" and "two-way symmetrical" models on the other. Many of the subsequent research and writings on public relations have highlighted the advantages of the "two way symmetrical" model with lofty accolades for the provision it makes for participatory, democratic and dialogic interaction between or among participants. It forms the cornerstone on which the excellence theory (later outlined by Grunig in 1992) is based. The underlying logic and advantages of two-way symmetrical $\mathrm{PR} /$ Communication model is its emphasis on the use of communication to negotiate with the public, resolve conflict and promote mutual understanding and respect between organizations and their stakeholders. Key to our argument in this paper is that social media are particularly well suited for and (more) adaptable to two-way symmetrical communication which we also contend is dialogic, participatory and democratic than traditional media; features which social movement activists would find beneficial and rewarding for their causes. Perhaps because of this provision that the social media make for democratic two-way communication, there is a growing body of literature examining the possibilities as well as drawbacks of the social media not only to facilitate civil society activism movement in the achievement of their many goals, but also their value for ordinary corporate communication. The goal of the paper is to elicit the various benefits or potential as well as any shortcomings of the social media for social movements activism. What characteristics or features of the social media could interface with the interests and activities of social movement activists? What advantages do social media have over conventional media with regard to social activist movements? These and similar underlying study questions informed and inspired the research. Specific research questions that guided the arguments and conclusions reached in this paper were: 


\section{Research Questions}

1). What opportunities and problems exist for social media use in contemporary grassroots movements?

2). How might the new media contribute or be capable of contributing to the social movement activism?

3). How might this new social media based or inspired form of activism be conceptualized as a new movement, or through the lenses of some existing or other reflections?

4). In what ways may messages shared on social media be considered "democratic," and are there ways in which they could be considered "problematic?"

5). What precautions and guidelines might help strengthen the use of new and social media for grassroots movements and activism around the world?

\section{Opportunities for Participatory Grassroots Democracy}

Ross and Burger (2014) sought to investigate the underlying motivations for New Zealand politicians' engagement with their publics and discovered that, contrary to expectations, and in spite of the provisions for democratic and participatory communication via social media, much of the political communication in New Zealand is still predominantly use one-way public information model; used by politicians to give information to the public - and the various politicians' "followers." The study found much of the political communication taking place via social media in New Zealand to be centered on politicians providing information using one-way channels to the public in order to make and keep themselves both visible and 'hip' in the eyes of the public (Ross and Burger, 2014, p. 46). Such uses limit the scope of social media in terms of the enormous opportunities they provide for dialogue and debate which are crucial for citizen engagement. Major part of the problem has to do with the monologic nature of such a model, which does not take advantage of the enormous potential for dialogue offered by social media. New Zealand politicians use Facebook posts to "broadcast information" rather than take full advantage of the medium as enabling two-way flow of information (see Ross, Fountaine, and Comrie, 2015, 251). According to a study by Obholzer and Daniel (2016) which surveyed members of European parliament, one of the key advantages of social media use in political campaigning is their ability to offer politicians a means to contact voters remotely and at low cost - without the usual hefty media buying budgets attached to using traditional media. 
Other studies that have investigated social media for their potential for participatory (democratic) communication have listed among their many benefits facilitation of two-way dialogue among younger users. One such study by Briones, Kuch, Liu, and Jin (2011) that investigated the American Red Cross' public relations practices with their key publics through Twitter and Facebook revealed that effective social media usage in corporate communication is both necessary and essential in the emerging digital age; social media help facilitate mutual understanding by removing or minimizing suspicion, and therefore can build strong and lasting relationships.

Debies-Carl (2015) examined the promises and any possible obstacles in social media usage in subcultural resistance, arguing that the shift from print to digital media platforms marked by proliferation of personal computers and Internet ushered in hope for greater individual liberties. Such a dream for greater liberties which he called "cyberlibertarian dream" brought with it the emergence of a relatively new online world encompassing free association, egalitarianism and self-determination that would exclude no one (see also Barlow, 1966; Kahn and Kellner 2003; Turkle 1997). Besides the obvious advantages that inclusivity and widespread access to the media brings, this inclusive analogy and portrayal of social media presents another advantage of social media in the way it responds to one of the main concerns of critical communication scholars; the notion that conventional mass media such as the press, radio, television are under the control of economic elites and governments tall around the world. The Internet and social media based upon it, on the other hand, are widely available giving the average person greater input and control. This openness and widespread availability makes the Internet (and Internet-based social media) difficult to dominate by special interests or media moguls. (see Leary 1994; McChesney 2008).

These aspirations and hopes for a widely-available, highly technology-based future with the Internet at its center closely mirror the aspirations of many resistance-based subcultures which Debies-Carl (2015) referred to as "Cyberlibertarians." Internet users are not perceived as passive, innocent and exploitable consumers, but as self-directed agents who take an active role in constructing themselves and their social reality through free, continuous and ongoing interaction. (p. 681). At the individual level, these technologies provide users with a number of benefits vis-a-viz subcultural resistance: “opportunities for peer-to-peer learning, a changed attitude towards intellectual property, the diversification of cultural expression, the 
development of skills valued in the modern workplace, and more empowered conception of citizenship." (Jenkins et al. 2006, p. 3). At the collective level, on the other hand, the potential of these emerging digital technologies for activist movements is strong enough to significantly empower such movements and even create grassroots revolutions (see Earl and Kimport 2011; Tsekeris 2009).

Elsewhere, a study by Melissa Graham (2014) on the impacts social media on government PR practices by government departments identified three main advantages; a) promoting dialogue along the two-way symmetric model outlined by Grunig and Hunt, b) engagement and interaction with the various key publics - especially beneficial during times of crisis, and c) unconstrained in their ability to enable and enhance democracy through the open, interactive and transparent ways that prompt citizens to learn about and participate in government programs.

More recently, many new and significant developments have taken place demonstrating the potential of the social and new media to galvanize public opinion and rally people around important causes and issues locally, nationally, regionally and globally (Khondker, 2011). Although systematic analysis of the role of the media in rallying people for political causes such as the Arab Spring that led to the overthrow of several governments perceived to be dictatorial in the Middle East and North Africa is sparse and in some ways contradictory about the true extent to which the social media may have played a role in causing /'igniting' or giving momentum to the "Spring" movement, there is little doubt that many of the protesters "gathered" online before people ventured out into the Streets and Squares for the mammoth political rallies that followed. While the 'Protester' gained prominence and notoriety by being declared surprise "Person of the year 2011" by Time Magazine, sufficient attention has not been paid to analyzing and documenting advantages and unique provisions of the channel/s they may have used to bring about one of the most significant changes to the political history of the Middle East. It is this perceived missing link or gap in media scholarship that we seek to bridge while arguing that social media may be potent instruments for more democratic and participatory communication through deliberative participation by citizens to achieve collective social movement goals through participatory, democratic goals. 
Bratic suggests that "it is safe to say that media is an environment for the formation of cultural narratives, images and perceptions - both good and bad (Severin and Tankard 1992). Therefore, it is hard to imagine a more appropriate venue than the media, where conflicts over narratives, images and perceptions can be transformed in a non-violent fashion. Based on previous research of media effects it is understood that the media may have only limited power to directly inject a certain behavior into people's minds (Klapper 1960; Katz and Lazarsfled 1955); but it can equally be argued that effects of the media are neither minimal nor negligible since the media rarely act as a sole agents of change by influencing people's beliefs, attitudes and opinions over time (Hovland et al. 1949; Severin and Tankard, 1992)."

Based on preceding discussions, it therefore becomes clear that social media have several advantages or benefits which social movement activism can benefit from. These benefits or opportunities include without being limited to, facilitation of democratic and participatory communication; cost effectiveness; widespread access to more people (emphasis on disadvantaged and marginalized groups), non dominance by special elites or interests, and the provision they make for dialogic (two-way) as opposed to monologic (one-way) communication, among other benefits.

\section{Digital Media Activism and Social Movement Theory}

"The extant traditions of social movement theory (the theories that have been advanced in Western Europe and the US during the past three decades) are "typically discussed under the rubric of two paradigms: the mainly American-based resource mobilization approach (RMT) and the mainly European-based theories of new social movements (NSMs). Resource mobilization theory focuses primarily upon how movements form and engage in collective action; new social movement formulations focus primarily on why specific forms of collective identity and action appeared in late 20th-century Euro-North American societies and on their sociopolitical significance” Melucci, 1989)" (Carroll and Hackett, 2006)

Through the effective use of social media, governments have lost their traditional control or monopoly on information flow and non-state actors and citizens have greater and more aggressive role in the dissemination of information for a variety of causes and in situations of conflict. Social networking sites help and enable members of the public to work as citizen journalists and contribute to the flow of information from the streets and share such 
information with the rest of the world. Social media can and often help citizens to break through the boundaries or walls of even the most authoritarian societies. In such societies the mainstream media are usually under the monopoly of the elite and can hardly effectively perform the media's traditional watchdog role as the $4^{\text {th }}$ estate that safeguards the interests of the public against possible abuses and excesses of government. Nor can such media be relied upon to supply accurate information to the public on sensitive issues, especially during times of conflict. Indeed times of tension have caused us to witness desperate efforts by governments to condemn or regulate the social media (during Gezi Park protests in 2014 in Turkey, 2016 elections in Uganda - when government of Uganda made frantic efforts shut down all social media on the day of Presidential election in March 2016 and again in May when President was sworn in (http://www.monitor.co.ug/News/National/Government-shutsdown-social-media-again/-/688334/3201024/-/cx1mkv/-/index.html) many a times in authoritarian regimes governments are often the perpetrator of conflict with their own citizens. The social media are unlikely to experience such constraints and would be better placed to perform this (watchdog) function compared to the mainstream media which are subjected to several overt regulations both within the news organizations themselves and externally by governments; by contrast, social media are comparatively free, spontaneous and interactive.

While analyzing contemporary contributions of the social media in the spheres of justice and peace, Lievrouw (2011) gave a succinct summary of the potential that social media present to organized groups of citizens around the world thus: "New media have played an indispensable role in the global justice movement by drawing together a widely diverse range of groups and causes into a globally scattered, loosely articulated, self-organizing movement capable of responding to major multinational policy bodies and staging high visibility events all over the globe" (p. 163). This could easily be seen in the Arab Spring in 2011 and Gezi Park protests in Turkey in 2014 where demonstrators effectively used the social media to make their voices heard both locally and internationally. Studies by Kuruç and Opiyo (2014), Kahn and Kellner (2004) added a new dimension by highlighting the potential in the worldwide web to propagate anti-war pro-peace messages all around the world, arguing that, the global internet is creating the base and the basis for an unparalleled worldwide antiwar/pro-peace and social justice movement during a time of terrorism, war and intense political struggle. This is not to say the social media are all about peace activism and peaceful 
initiatives. As is now commonly known only too well, many terrorist networks, hate speech by individuals as well as hatching of plots by people with bad intentions is often done online. Usually, one of the first places security officials and law enforcement agencies check when one commits heinous crime is to the concerned person's recent activities on social media. Thus, the social media also have potential for misuse and abuse - or have problematic aspects; the focus of our next discussion.

\section{Problematic Aspects of Social Media}

By the preceding discussions, we do not by any means intend to suggest that social media are all only useful mobilizers of people for effective political or social action. They do have their disadvantages; they have sometimes been used to mobilize people to hate or engage in conflict. In the East African country of Kenya, social media have become double-edge sword being used systematically to promote peace and national cohesion on the one hand, and actively being used by various individuals and groups as forums to fan ethnic chauvinism and hatred since the disputed national election of 2007 and subsequent mayhem that took distinct ethnic pattern, on the other.

The contributions of mediated digital activism to bring social change by either maintaining peace or mobilizing for conflict and violence are based on the kind of communication that media provide. In his book An Introduction to Political Communication, McNair (2011) summarized functions of communication media in an 'ideal-type' democratic society as "to inform citizens of what is happening around them..., educate as to the meaning and significance of 'facts', to provide a platform for public political discourse, to give publicity to governmental and political institutions- the watchdog role of journalism, and finally, to serve as a channel for the advocacy of political viewpoints" (pp. 19-20). The gate-keeping or watch dog role of the traditional media has been changed by the emergence of the new media. As Cardoso and Neto argue in their article Mass Media Driven Mobilization and Online Protest "new media provide alternative communication spaces in which information can develop and circulate widely with fewer conventions or editorial filters than in the mainstream media". Nowadays there is also information flow from the new media to the mainstream media especially during the times of conflict where the mainstream media are controlled or censored by the operatives of the government. 
Creating a platform for the dissemination of information is one of the fundamental roles of mass media. This is especially crucial in conflict situations. Many scholars claim that conflict is an inevitable aspect in the contemporary societies of our global world. (Blackman 2003, Lynch 2007, Reuben 2009, Tahir 2009). In such volatile areas the use of social media by providing decent and objective information or forming another platform for authoritarian control either ascends or descends the degree of violence and conflict. Social media either contribute to conflict transformation or intensify the conflict. Hence in the use of social media we have the two sides of a coin which are the democratic ones and the problematic ones.

In this part of the study, we attempt to discuss the use of social media in conflict situations and their challenges in peace building. Our main focus is the exploration of the challenges of social media in conflict reporting. In such times conflict sensitive reporting or conflict sensitive journalism is essential to contribute to the peace building process otherwise violence and crime will accelerate within the societies.

Noelle-Neumann (1984) explained how one sided media content generates a dominant opinion that silences the minority opinion. During the time of conflict "media systems... will usually be underdeveloped and rarely diverse. It is not uncommon to find that only a few news sources dominate the media environment." (Bratic, 2006, p. 5). In media the selection of the topics, framing of the issues and the distribution of concerns all contribute to either facilitating to peace building or intensifying conflicts.

Agenda-setting is crucial for political sphere. It is a vital point in public relations and activism. It creates awareness within societies. It may contribute to peace building and vice versa. Brewer et al. as cited in Bahador claims that "through its agenda setting function, the media defines who matters in the world and who does not. Through framing the media defines which countries and peoples considered in a positive way and which ones should be viewed negatively" Agenda-setting theory claims that "the media do not tell the public what to think but rather what to think about- thus the terms of public discourse are set by what is covered in the media". (Hanson, 2011, p.59) McCombs and Show (1972) point out that the media constantly present issues suggesting individuals in the society what they should think about, have feelings about. Hence, media have the power to influence the public about the social reality. Conflicts are just one example of such realities. A well-known UNESCO constitution 
preamble points out that "wars begin in the minds of men". Bahador in the article The Media and Deconstruction of the Enemy Image outlines the construction of the enemy images by the media. Social media have great impact in the construction of such images particularly because social media may lack the critical perspective.

Manual Castell's "The Rise of the Network Society" (1996), and "Communication Power" (2009), initiated the sociological discussions about the effects of the new media on the $21 \mathrm{st}$ Century society. As the 20th Century drew to a close and during nearly a decade and a half of the 21 st Century the world wide internet has become a major tool for the spread of participatory democracy and cyber activism throughout the world. Howard (2011) defined cyber-activism as "the act of using the internet to advance a political cause that is difficult to advance offline" (p.145)

Although scholars are still debating the extent to which the media alone could be credited with causing what is now generally referred to as the Arab Spring, there is little dispute about the important role that the social media in particular played in the process during and after the social revolutions started. The Arab Spring (reference to popular uprisings by large numbers of citizens in many Arab and North African countries which had been led by strongmen who hitherto did not tolerate dissent) started in Tunisia with "the self-immolation of a market stallholder, Mohammed Bouaziz, on December 10, 2010" (New Internationalist). The revolutionary political movements that started in Tunisia in December 2010 quickly spread to the other countries in Middle East and North Africa (MENA), leading to popular overthrow of regimes presumed to be 'dictatorial' - initially President Ben Ali in Tunisia and Hosni Mubarak in Egypt - but later spreading to Yemen, Libya, and Syria, among others. Much of these political developments have been attributed by many to social media activism, a term commonly used to refer to internet-based microblogging sites such as Twitter, or social networking sites like Facebook and using cell phones to take and upload videos on these sites. (Kuruç and Opiyo, 2014).

According to many accounts, those who witnessed Mohammed Bouaziz self immolation recorded it with their mobile phones and it quickly went viral igniting a seeming domino effect of protests in Tunisia which later spread to other parts of the Arab world. According to O'Donnell (2011) conversations about liberty, democracy and revolution on blogs and on 
Twitter preceded mass protests in Tunisia. The protests quickly spread to Egypt, Libya, Syria and Yemen, which could suggest that they may have been carefully planned with clear political motives. So far, the protests have led to the ouster of heads of government in Tunisia, Libya, Egypt and Yemen. (Egyptian protesters have ousted two presidents since). Both mainstream and social media collaborated in spreading the revolution. "From 2006, the AlJazeera training center systematically started training youth activists on social networks and citizen journalists free of charge.” (Ishiai, 2013; Kuruç and Opiyo, 2014).

While analyzing the role of the media in the Arab Spring, Khondker (2011) concluded that the new media was one of three factors which, together with social and political factors that caused the social revolution in the Middle East and North Africa (MENA) region, arguing that, the social media played a particularly important role - especially in the absence of an open media and well organized and functioning civil society. This provided activists with "horizontal connectivity" in social mobilization, besides heralding a new era of 'convergence' (of purpose) between new media and conventional media.

The mainstream and social media collaborated in spreading the revolution. "From 2006, the Al-Jazeera training center systematically started training youth activists on social networks and citizen journalists free of charge." (Ishiai, 2013). This action four years before the uprisings started may indicate that the media may not have worked in a political vacuum; possibly implying there was coordinated activism as(Kuruç and Opiyo (2014) argued.

However, unlike the Gezi Park protests in Istanbul where traditional media were uncharacteristically silent especially in the first days of the protests, in the case of Arab Spring these (conventional) media media played a particularly active role - especially $\mathrm{Al}$ Jazeera television which not only provided prior training to journalists but also widely covered the protests - leading to the now famous arrest of four Aljazeera journalists who were sensationally sentenced to jail terms in Egypt. While tracing the role of Aljazeera in the Arab Spring protests Manuel Castells (2011) states that,

"Al Jazeera has collected the information disseminated on the Internet by the people using them as sources and organized groups on Facebook, then retransmitting free news on mobile phones. Thus was born a new system of mass communication built like a mix between an 
interactive television, internet, radio and mobile communication systems. The communication of the future is already used by the revolutions of the present. . .". It is therefore evident that social media, Al Jazeera television and mobile phones played an important role in the communicating the Arab Spring to the global community.

In many nations of the world where there is official restriction on people's freedoms, the news media have been used to control the flow of information to serve to the needs and interests of the government. The conventional media in Middle East and Turkey have by and large been either under the control of the state or the rich business people with powerful connections with the ruling political elites. This could explain the public's resort to and reliance on the new media to act against such regimes. It is in partial recognition of this that Kuruç and Opiyo (2014) argued that, in the Middle East the new media have been used not only to mobilize citizens in one country or state to have large scale demonstrations but also to ignite and influence activities (of defiance) in the nearby countries as well.

The power of the social media in the Arab Spring peaked during the latent stage of the uprisings (Lindsey, 2013). However, the traditional media took over as the physical activities of the revolutions started. In areas where the traditional media were not granted easy access, synergy emerged between citizen reporters and the international agencies to get the events across to the world. (Ishiai, 2013)

Some scholars and critics have, however, argued that the role of the media in the Arab Spring has been widely overstated. "It was not laptops that marched on Tahrir Square but people with a common cause. (New Internationalist, December 10, 2010). On-the-ground activities like shooting, bombing, kidnapping and negotiating provide the decisive moments in insurgencies. Obviously, these are clear political activities. The support (financial, logistic, media etc.) given to the "revolutionaries" in Libya by the Western powers was the decisive factor in the Libyan revolution. The framing of the events in the international media is only a product of the underlying political and economic interests of the major powers of the global system. The inability of the "rebels" to topple the Syrian government despite the massive support by the West and the negative narratives about the Syrian government is a proof that the media role in the case of Libya, Tunisia, Egypt and Yemen are often overstated. The war in Syria has 
reached a stalemate because of the counterweight of Russia and Iran on the side of Bashar AlAssad, and the other coalition led by the US, Saudi Arabia and Turkey, on the other.

The media "cannot replace the physical actions required for successful revolutions" (Lindsey, 2013). The quotations below aptly sum up the main thesis on the (potential) role of the media in the uprisings. "Social media may not have been the spark that set the fire, but it certainly provided the oxygen that caused it to spread" (Pfeifle, 2012). Moreover, "it is important to understand that new platforms of social media didn't cause Arab Spring but played a role of communication that aids the revolutions in the long run." (Kassim, 2012). The conflicts might amplify and lead to chaotic results or bring some intended solutions to the societies. Social media function as a potentially useful tool from which much social capital can be derived; but it also has the power and potential of a 'double-edged sword' as suggested by Howard (2002) with opportunities and benefits on one side, and risks and destructive consequences, on the other, lying primarily in how it is used. The impact of the social media can be negative when they disseminate messages of intolerance that manipulate public opinion. In conflict situations social media has the tendency to mobilize masses either in positive or negative dimensions. Especially in autocratic regimes where there is control over the mainstream media social media took the role to contribute to participatory communication. The abuse of social media might escalate and lead to non-productive results. The motto "if it bleads it leads" shows that if the issues of the news are violent then they take the attention of the media and the audiences.

Surfing the Internet and searching the news may raise the probability of depression within societies. Especially if these are the places within the conflict zones of the world 


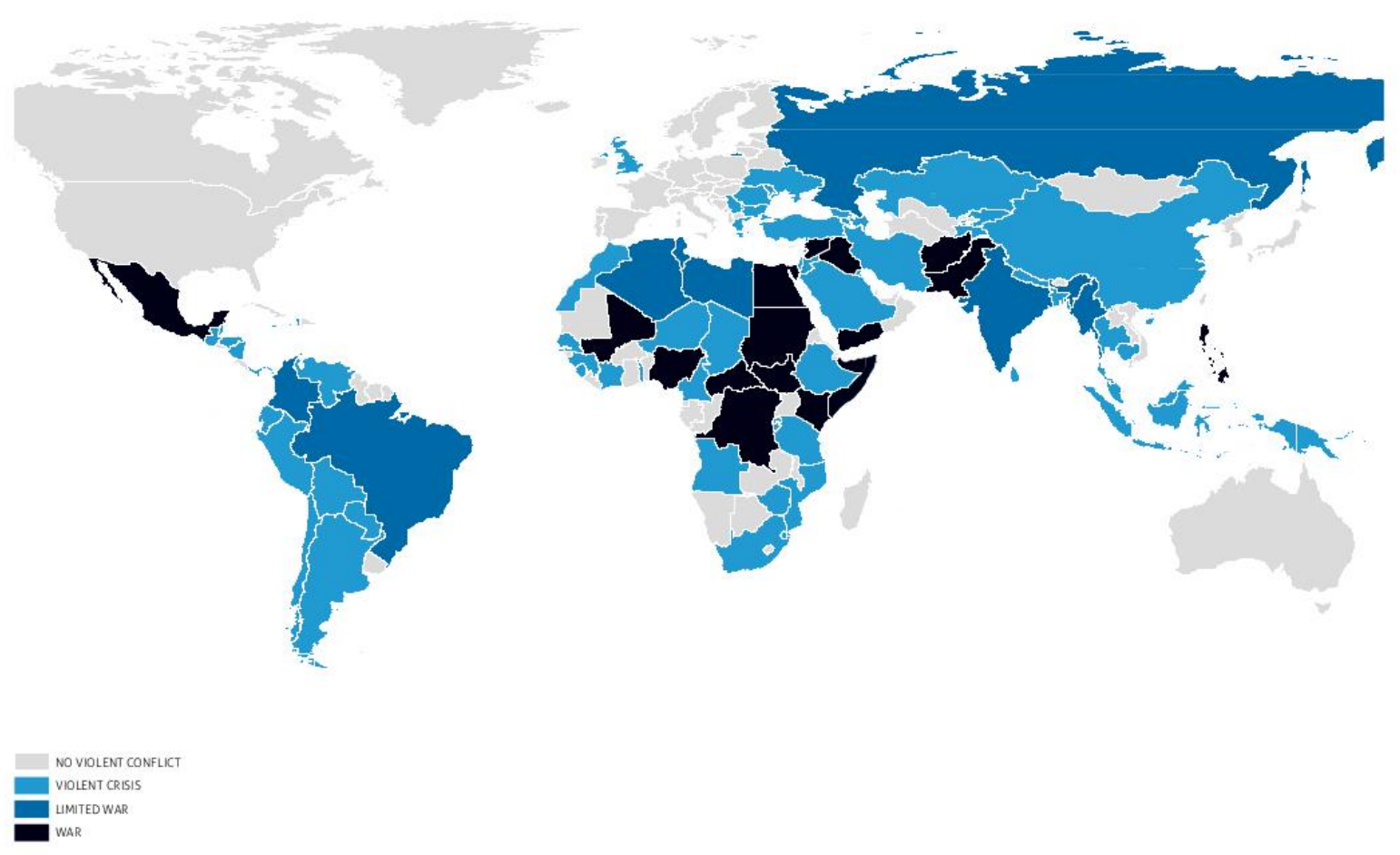

Fig 1.1 Global distribution of conflicts (source: Conflict Barometer 2013, Heidelberg Institute for International Conflict Research).

A lot of violent news create a feeling of hopelessness and helplessness among the citizens in such fragile places. Citizen who are exposed to such media are more likely to feel that their communities are unsafe. They believe that the world is a dangerous place to live. Gerbner argues that "heavy television viewing cultivates a response ... calls the mean world syndrome" (Hanson 2011, p. 64). Similar to Gerbner's idea such people who are exposed to such negative media coverage are more fearful about their sorroundings.Nowadays, in the social media and visual media we have more emotionally laden material than from the print media.

\section{Social Media Activism}

Being a skeptic of the contributions of social media in social change and conflict resolution, Malcolm Gladwell suggests that "social movements need more conventional tools of organizing than those provided by new media" (2010). Gladwell further adds that "Facebook activism succeeds not by motivating people to make real sacrifice but by motivating them to 
do things that people do when they are not motivated enough to make a real sacrifice" (2010). Moreover he argues that "social change can be achieved by high-risk activism and not by low-risk activism promoted by social media".(2010) Melucci points out that "the empirical unity of a social movement should be seen as result rather than a starting point" $(1996, \mathrm{p} .40)$. Habermas (1987) as cited in Caroll and Hacket (2006) has seen the new media activism through the lens of social movement theory as "defensive in character, his formulation is especially instructive in thinking about 'emancipatory movements':

... those which advance a resolution of the welfare-capitalist crisis which would involve the 'decolonization of the lifeworld'. This would involve the withdrawal of system-integration mechanisms from some aspects of symbolic reproduction; the replacement of (some) normatively secured contexts by communicatively achieved ones; and the development of new participatory democratic institutions which would regulate markets, bureaucracies and technologies." (Ray,1993:62). Habermas argues that the new social movements in values and attitudes express a 'silent revolution' (1987: 392).

In an interview that he has given to El Pais newspaper, Zygmunt Bauman considered social media as a trap. Bauman is another skeptic about the way people protest through social media. He adds that "social media don't teach us to dialogue because it is so easy to avoid controversy... most people use social media not to unite not to open their horizons wider, but on the contrary, to cut themselves a comfort zone where the only sounds they hear are the echoes of their own voice, where the only things they see are the reflections of their own face". (2016)

Hence it could be said that social media can contribute to and increase participation however participation is not enough to contribute to contemporary grassroots movements and bring democracy and social change to the societies. Social media is an effective tool in the dissemination of information and to be in dialogue however it is not enough for progressive activism. Digital communication is important in creating networks and arranging coordination across diverse geographies however as the above critics mention social change requires "highrisk activism" as well. 
According to Ethan Zuckerman's "cute cat" theory of digital activism "the dominance of trivia on social networking sites is in fact beneficial for the use of such sites by activists" (Joseph, 2012). For Shirky "a related danger for governments in shutting down certain sites is that they may focus greater attention on those sites than would have otherwise existed; the previously apathetic suddenly develop the curiosity to find out what all the fuss is about." (Joseph, 2012)

Social media can also be used to disseminate biased/wrong information as well. Sometimes the misinformation shared in the social media can become global news in a short period of time. Morozov as cited in Joseph's article Social Media, Political Change and Human Rights (2012) points out that "it is wrong to assume that all bloggers in Russia, China, or Iran favor democratic reforms and pluralist tolerance. Many such bloggers are more hardline than their government; the blogosphere in authoritarian States harbors reactionaries just as it does in the West. Such reactionaries can even be cultivated to report on perceived subversive activity, as has occurred in Thailand, Saudi Arabia, and China, or to engage in cyber-attacks on dissident websites".

As stated in Hoffmann's article Confronting the Condrum of Hate Speech digital communication tools and the internet "have added new modes of delivery for rumour, racist slurs and calls for (organized) violence" also see (Stremlau and Price, 2009).

\section{Suicide Bomber Explosion in İstanbul}

On the $19^{\text {th }}$ of March 2016, there was an explosion in Istanbul's İstiklal Avenue. The explosion has been caused by a suicide bomber which is a very common method in the explosions caused by terrorist attacks lately in Turkey. Right after the explosion the Turkish authorities released a temporary ban of broadcasting. Similar to their actions in the previous terrorist attacks in Turkey, the prime minister's office announced a temporary ban on media coverage of the blast. The officials citing a 2011 Turkish law rushed out a temporary ban to protect the national security. State media watchdog (the Turkish Supreme Board of Radio and Television) imposed a ban on broadcasting images of the blast. The government authorities particularly ban the coverage of pictures of the bombing or images of the victims that might create "a feeling of panic". Despite the temporary ban of broadcasting the images of the blast continue to be shown on social media. David Diaz-Jogeix director of programs at press 
freedom group Article 19 told the World Post by an e mail that " media bans imposed by the Turkish government are rarely effective... some media simply defy the bans... Additionally even where Turkey is preventing domestic broadcasting, there are other sources of information including social media and international media." During such times when the mainstream media do not cover the news, the new media may spread information that mislead the society. Especially in such dramatic attacks like the terrorist attacks in Taksim, the people may share biased information or violent scenes in the social media and contribute to the spread of fear among the society. Assoc. Prof. Dr. Levent Eraslan mentions that during conflict times "when the society is in panic and share the news of the event in the social media these sharings bring a fearful atmosphere and the daily routine of the citizens are affected negatively." Eraslan further adds that "sharing of false information in the media contribute to fear". This is true of the sharings in the social media right after the explosion in Taksim. The videos on Facebook showed the panic of people. A group of people ran away from the site of the explosion right after the attack. In some of the sharings on Facebook the decapitated head of the suicide bomber and the bloody images of the victims were shared. Such images increase the tension and the fear within the society and people feel insecure in their own surroundings. This situation could easily be explained with the mean world syndrome of Gerbner where the people in the society feel insecure. Media bans also contribute to this feeling of insecurity.

Moreover, right after the explosion in Taksim, there were sharings in social media claiming that there are explosions in Nişantaşi, Bakırköy, Kadiköy and Ümraniye. These sharings increase the fear and tension among the citizens. Ali Murat Kırık, an Assistant Prof. Dr. from the Faculty of Communication at Marmara University claims that "terrorist organizations through the use of social media affect the perceptions of the citizens, contribute to the destruction of the life routine and cause a chaotic environment." (Nabız Newspaper, 20 March 2016).

Sharing violent images like the bloody images of the victims after the terrorist attacks affect the psychology of the citizens negatively. Hence, during such conflict times the people should be selective of what they should share. They should share the news that they are sure about and they should not share the bloody images. The people should stay away from the motto "if it bleads it leads" because this will amplify the chaos and fear within the society. 
During the times of crisis the society need more up to date information than ever. Hence we believe that the temporary ban of the media coverage do not contribute to peace-building and conflict resolution. During such times that the mainstream media do not cover the news, the citizens tend to move to the social media. They follow the recent information from the social media sites. Yet, it would be better if the information shared on the social media is supported by the mainstream media. So the citizens will be able to check the validity of the news shared in the social media. The use of conflict sensitive journalism is really significant here. The demerits of the social media might be minimized by the regulations that would safeguard people's freedoms while protecting users from abuses and the adverse effects often inherent within the new media applications.

Here, social media literacy become crucial. The citizens should not believe in everything they see on the social media sites but should ensure they check the validity of the information shared on the social media sites from the more trustworthy news sources. The government officials especially during the times of conflict should not ban the media coverage and provide the citizens the platform to get true information from the conventional media.

\section{Conclusion/s}

Our main task in this study was to articulate and document the opportunities and potential of social media for individuals and institutions involved in social movement activism to present and advance their various causes and engage their publics. It undertook to do so while also eliciting the known and potential problems that could emerge in the process of realizing the many benefits of social media in the achievement of what we've alternately called digital activism, cyberactivism, or mediated activism. The study's core arguments were guided by five research questions revolving around the role of social media in civil society movement activism vis-a-viz theoretical stipulation of two-way symmetrical communication model advanced by Grunig and Hunt, participatory, democratic and dialogic communication, and their relevance and potential for and impact on social movement or grassroots activism through social media. The downside of social media were also examined.

Available evidence and analysis clearly shows that social media have enormous potential for social media activism. Advantages include, without being limited to, facilitation of democratic and participatory communication; cost effectiveness; widespread access to more 
people (emphasis on disadvantaged and marginalized groups), non dominance by special elites or interests, and the provision they make for dialogic (two-way) as opposed to monologic (one-way) communication, quite as strongly advocated by Grunig and Hunt (1984), Grunig (1992). Consequently, the social media are more likely than the traditional media to help realize what one scholar referred to "Cyberlibertarian dream" platforms marked by proliferation of personal computers and Internet ushered in hope for greater individual liberties. Such a dream for greater liberties brought with it the emergence of a relatively new online world encompassing free association, egalitarianism and self-determination that would exclude no one (participatory, inclusive).

At the individual level, these technologies provide users with a number of benefits for contemporary grassroots movements ranging from opportunities for peer-to-peer learning, mobilization towards a cause, the development of skills valued in the modern workplace, and more empowered conception of citizenship, among other benefits. At the collective level, to paraphrase one scholar, the potential of these emerging digital technologies for activist movements is strong enough to significantly empower such movements and even create grassroots revolutions. In addition, social media may enhance political participation and dialogue via the exchange of opinions and ideas worldwide regardless of frontiers, thereby creating the needed awareness to build society. Because the autocratic regimes who feel threatened by the interactive usage of social media platforms might be willing to control them and make them voiceless...In such cases the civil societies with the use of social network sites may have the chance to be informed about the issues that the governments try to control. Hence, the social media create a powerful platform to promote both national and global democracy and contribute to grassroots movements.

It is difficult to draw the line between the promises and problems of social media. We can say that social media can contribute to and increase participation, however, this kind of participation is not enough to contribute to contemporary grassroots movements and bring democracy and social change to society. Some scholars have contended that social media by themselves are not sufficient instruments for progressive activism, implying that additional inputs are required. As Zuckerman put it social change requires "high- risk activism" as well. Abuses by criminals and terrorist groups and organizations have equally been rampant and have contributed to the heightening of fear in different societies. Other shortcomings of social 
media include their susceptibility and misuse in the dissemination of biased and inflammatory information by wayward individuals and groups, in the advancement of their equally adverse causes. Disclosure of such biased information and criminal acts particularly during the times of conflict amplify the chaos and fear within society and may be seen to construe a threat to national and global security. In conclusion, we recommend that during such times social media literacy, conflict sensitive reporting and critical consumption of information by citizens should be encouraged in achieving and maintaining democratic citizenship and reducing the impact of crime within the society. In addition, we suggest national initiatives be taken to maximize the benefits of social media while minimizing, or at least containing the threats through incorporation of independent but limited guidelines and regulations that would safeguard people's freedoms and rights while protecting users from abuses and adverse effects. 


\section{References}

Bahador, B. (2015). "The media and deconstruction of the enemy image", in Communication and Peace Mapping-an emerging field edited by Hoffmann and Hawkins; Routledge.

Barlow, J.P. (1996). “A Declaration of the Independence of Cyperspace.” http://w2.eff.org/Misc/Publications/Joh_Perry_Barlow/barlow_0296.declaration.txt.

Blackman, R. (2003). Peace-building within our communities, Tearfund 2003, retrieved from http://tilz.tearfund.org/media/Files/TILZ/Publications/ROOTS/English/Peacebuilding/Peace_E.pdf

Brewer, P. R., Graf, J., G., and Willnat, L. (2003) "Priming or Framing: Media Influence on Attitudes Toward Foreign Countries”. International Communication Gazette, 65 (6): 493-508.

Briones, R.L., Kuch, B., Liu, B.F., and Jin, Y. (2011). Keeping up with the digital age: How the American Red Cross uses social media to build relationships. Public Relations Review, 37: 37-43.

Bratic, V. (2006). "Media effects during conflict: Evaluating media contributions to peace building". conflict \& communication online, vol. 5, No.1.

Bratic, V. (2015). Beyond Journalism: expanding the use of media in peacebuilding, in Communication and Peace-Mapping an emerging field edited by Hoffmann and Hawkins; Routledge.

Brewer, R., Graf, J. and Willnat, L. (2003). Priming or Framing: Media Influence on Attitudes Toward Foreign Countries. International Communication Gazette, 65 (6): 493-508.

Cardoso G. \& Neto, P. P. "Mass media driven mobilization and online protest-ICTs and the pro-East Timor movement in Portugal", in Cyberprotest-New Media, Citizens and Social Movements, edited by Wim Van De Donk, Brian D. Loader, Paul G. Nixon and Dieter Rucht, Routledge, Taylor and Francis e-library, 2005.

Caroll, W.K. \& Hackett R.A. (2006). "Democratic media activism through the lens of social movement theory" . Media, Culture and Society, Sage Publications, retriewed from http://mcs.sagepub.com/cgi/content/abstract/28/1/83

Castells, M. (1996). The Rise of the Network Society (Cambridge, MA: Blackwell).

Castells, M. (2009). Communication Power (New York: Oxford University Press). 
Castells, M. (2011). Interview posted on http://globalsociology.com/2011/02/07/thesociology-elders-on-the-socialmovements-in-tunisia-and-egypt/ (accessed 25 June 2011).

Charlotte, A. "Why Turkey Bans News about Terror Bombings, The World Post, 17 Feb. 2016, retrieved from: www. Huffingtonpost.com/entry/turkey-media-blackoutistanbul-bombing_us_56957080e4b086bc1cd5a364

Debies-Carl, J.S. (2015). Print Is Dead: The Promise and Peril of Online Media for Subcultural Resistance. Journal of Contemporary Ethnography, 44(6): 679-708.

Delvin, K. (2016). Trump would be 'coward' to snub Scotland mosques, in USA TODAY. Retrieved from: http://www.usatoday.com/story/news/world/2016/06/10/donaldtrump-scotland-coward/85684514/

Delvin, K. (2016). Scottish Muslim leaders invite 'ignorant' Trump to visit mosque, in USA TODAY. Retrieved from:

http://www.usatoday.com/story/news/world/2016/06/08/scottish-muslim-leadersinvite-ignorant-trump-to-visit-mosque/85587828/

Dercon, S. and Gutierrez-Romero, R. (2012). "Triggers and Characteristics of the 2007 Kenyan Electoral Violence.” World Development, Vol. 40, 4: 731-744. Retrieved December 8, 2015 from:

http://www.sciencedirect.com/science/article/pii/S0305750X11002373.

Earl, J., and Kimport, K. (2011). Digitally Enabled Social Change: Activism in the Internet Age. Cambridge, MA: MIT Press.

Gladwell, M. (2010). "Small Change: Why the revolution will not be tweeted," The New Yorker, 4 October

2010.http://www.newyorker.com/reporting/2010/10/04/101004fa_fact_gladwell?curre ntPage $=$ all

Graham, M.W. (2014). Government communication in the digital age: Social media's effect on local government public relations. Public Relations Inquiry, 3(3): 361-376.

Grunig, J.E. (1992). Excellence in Public Relations and Communication Management.

Hillsdale, NJ: Lawrence Erlbaum Associates.

Grunig, J.E., and Hunt, T. (1984). Managing public relations. New York, NY: Holt, Rinehart \& Winston.

Habermas, J. (1987) The Theory of Communicative Action. Boston, MA: Beacon-Press. 
Hanson, R. E. (2011). Mass Communication Living in a Media World, CQ Press, a division of SAGE.

Hoffmann, Julia (2015). Confronting the conundrum of hate speech. In Communication and Peace Mapping an emerging field edited by Hoffmann and Hawkins by Routledge.

Hovland, C. I., Lumsdaine C. I., and Sheffield F. D. (1949) Experiments on Mass Communication. Princeton: Priceton University Press.

Howard, R. (2002). AN OPERATIONAL FRAMEWORK FOR MEDIA AND PEACEBUILDING, Vancouver: IMPACS - Institute for Media, Policy and Civil Society.

Howard, P. N. (2011). The Digital Origins of Dictatorship and Democracy: Information technology and Political Islam (Oxford: Oxford University Press). http://www.ihrb.org/news/digital-dangers-case-study-safaricom.html

http://www.ethanzuckerman.com/blog/2008/06/20/kenya-citizen-media-in-a-time-of-crisis/ http://www.dw.de/social-media-become-kenyas-new-battleground/a-16687870

Ishiai, T. (2013, July 14). Media planted the seeds for Arab Spring uprisings. Retrieved May 8, 2014, from The Asahi Shimbun: http://ajw.asahi.com/article/views/opinion/AJ201307140034

Iyenger, S., and Kinder, D. (1987). News that Matters. Chicago, IL: University of Chicago Press.

Jenkins, H., Purushotma, R., Weigel, M., Clinton, K., and Robinson, A.J. (2006). Confronting the Challenges of Participatory Culture: Media Education of the $21^{\text {st }}$ Century. Chicago: The MacArthur Foundation.

Joseph, S. (2012) “Social Media, Political Change and Human Rights" Boston College International and Comparative Law Review, volume 35, Issue 1, http: //lawdigitalcommons. bc.edu/icrl/vol35/iss 1/3

Kahn, R., and Kellner, D. (2004). "New Media and Internet Activism: From the 'Battle of Seattle' to blogging." New Media \& Society, 6 (I), 87-95.

Kahn, R., and Kellner, D. (2003). "Internet Subcultures and Oppositional Politics.” In Postsubcultures Reader, edited by D. Muggleton and R. Weinzierl, 299-313. Oxford: Berg. Kassim, S. (2012, July 3). Twitter Revolution: How the Arab Spring Was Helped By Social Media. Retrieved May 8, 2014, from Mic Network Inc.: http://www.policymic.com/articles/10642/twitter-revolution-how-the-arab-spring-washelped-by-social-media 
Kenyan electoral violcence. Retrieved from:

http://www.csae.ox.ac.uk/workingpapers/pdfs/2010-12text.pdf, on November 9, 2014. http://www.bbc.com/news/world-africa-29831262

Kuruç, K. U., and Opiyo, B. (November, 2014). "Mediated Activism: Prepondering the 'Activist' Use of Social Media in pursuit of Global Peace and Justice", conference paper, Fourth International Conference in Communication and Media Studies: If You Wish Peace, Care for Justice.

Katz, E. and Lazarsfled P. F. (1955). Personal Influence, The Part Played by People in the Flow of Mass Communications. New York: The Free Press.

Khondker, H.H. (2011). "Role of the New Media in the Arab Spring". Globalizations, 8, 5; 675-679.

Klapper, J. T. (1960). The Effects of Mass Communication,Glencoe:Free Press.

Leary, T. (1994). Chaos and Cyberculture. Berkeley: Ronin

Lievrouw, L. A. (2011). Alternative and Activist New Media. Malden, MA: Polity Press. Lindsey, R. A. (2013, July 29). What the Arab Spring Tells Us About the Future of Social Media in Revolutionary Movements. Retrieved May 7, 2014, from Small Wars Journal: http://smallwarsjournal.com/jrnl/art/what-the-arab-spring-tells-us-about-thefuture-of-social-media-in-revolutionary-movements

Lynch, J. (2007).Peace Journalism and its discontents, Conflict and Communication Online, vol.6, No.2.

McCarthy, J. D., McPhail, C., and Smith, J. (1996). "Images of Protest: Dimensions of Selection Bias in Media Coverage of Washington Demonstrations, 1982 and 1991.' American Sociological Review 61(3):478-99.

McChesney, R.W. (2008). The Political Economy of Media. New York, NY: Monthly Review McNair, B. (2011). An Introduction to Political Communication (5th ed.). London and New York, NY: Routledge.

McCombs, M. E., \& Shaw, D. L. (1972). The Agenda Setting Function of Mass Media. The Public Opinion Quarterly- JSTOR, 36(2), 176-187. Retrieved October 23, 2014, from

http://www.unc.edu/ fbaum/teaching/PLSC541_Fall06/McCombs\%20and\%20Shaw \%20POQ\%201972.pdf

Melucci, A. (1989). Nomads of the Present. London: Hutchinson Radius. 
Melucci, A. (1996) Challenging Codes: Collective Action in the Information Age.

New York: Cambridge University Press.

Noelle-Neumann, E. (1984). The spiral of silence: Public Opinion-Our social skin. Chicago, IL: University of Chicago Press.

Obholzer, L., and Daniel, W.T. (2016). An online electoral connection? How electoral systems condition representatives' social media use. European Union Politics, 0(0): 121.

O'Donnell, C. (2011, September 12). New study quantifies use of social media in Arab Spring. Retrieved May 8, 2014, from University of Washington Web site: http://www.washington.edu/news/2011/09/12/new-study-quantifies-use-of-socialmedia-in-arab-spring/

Pfeifle, M. (2012, June 14). Changing the Face(book) of Social Activism. Retrieved May 8, 2014, from The Huffington Post Website : http://www.huffingtonpost.com/markpfeifle/social-media-political-activism_b_1594287.html

Price, M. E., and Stremlau, N. A. (2009). Media, Elections and Political Violence in Eastern Africa: Towards a Comparative Framework. Annenberg-Oxford Occasional Paper in Communications Policy Research. Online, accessed April 2, 2014, available at: http://global.asc.upenn.edu/fileLibrary/PDFs/PostelectionViolencereport.pdf.

Ray, L. (1993) Rethinking Critical Theory. London: SAGE.

Reuben, R. C. (2009). The Impact of News Coverage on Conflict: Toward Greater Understanding, Marquette University, Law School.45, 93(1), retrieved from http://scholarship.law.marquette.edu/mulr/vol93/iss1/8 or http://scholarship.law.marquette.edu/cgi/viewcontent.cgi?article=4926\&context=mulr Ricardo, Q. D., interview with Zygmunt Bauman, El Pais (in English) newspaper, "Social media are trap" 25 ene 2016, retriewed from: http://elpais.com/elpais/2016/01/19/in english/ 1453208692_424660.html Ritter, D., and Treschel, A. (2011). "Revolutionary Cells: On the Role of Texts, Tweets and Status Updates in Non-Violent Revolutions". Working Paper Presented at the conference on Internet, Voting and Democracy, Laguna Beach, California.

Ross, K., and Burger, T. (2014). Face to face(book): Social media, political campaigning and the unbearable lightness of being there. Political Science, 66(1): 46-62. 
Ross, K., Fountaine, S., and Comrie, M. (2015). Facing up to Facebook: politicians, publics and the social media(ted) turn in New Zealand. Media, Culture \& Society, 37(2): 251269.

Severin, W. J. and James W. Tankard (1992) Communication Theories: Origins, Methods, Uses of Mass Media, $3^{\text {rd }}$ edition, White Plains: Longman.

Tahir, B. A. (2009). Practical Guide: Tips for Conflict reporting. Islamabad: Termedia-

The Heidelberg Institute for International Conflict (HIIK) (Several authors). (2013). Conflict Barometer: Global distribution of conflicts. Heidelberg, Germany. retrieved from: https://hiik.de/de/downloads/data/downloads_2013/ConflictBarometer2013.pdf The New Internationalist. (December 10, 2010). World development book case study: the role of social networking in the Arab Spring. Retrieved from: newint.org/books/reference/world-development/cWorld Development book case study: the role of social networking in the Arab Springase-studies/social-networkingin-the-arab-spring/

Tsekeris, C. (2009). Blogging as Revolutionary Politics. Research Journal of Social Sciences, 4: 51-54.

Turkle, S. (1997). Life on Screen: Identity in the Age of the Internet. New York, NY: Touchstone

UNESCO. 1945. "The UNESCO Constitution.” UNESCO, November 16. Online, accessed April 22, 2014, available at: www. Unesco.org/new/en/unesco/about-us/who-weare/history/constitution/.

United Nations. (1948). The Universal Declaration of Human Rights. Retrieved from: http://www.un.org/en/documents/udhr/

Yıldızalp, M. (2016). "Yanlış Sosyal Medya Paylaşımları Teröre Hizmet Eder”, Ankara (AA), 23 March 2016, retrieved from: aa.com.tr/tr/turkiye/yanliş-sosyal-medya-paylaşımlarıteröre-hizmet-eder/542351 